\title{
Venous thromboembolism in laparoscopic surgery: experience in elderly
}

\author{
Rita Compagna, Gabriele Vigliotti, Tommaso Bianco, Maurizio Amato, Roberto Rossi, Francesca Fappiano, \\ Giovanni Aprea, Bruno Amato*
}

From 26th National Congress of the Italian Society of Geriatric Surgery

Naples, Italy. 19-22 June 2013

\section{Background}

In the last years venous thromboembolism has became one of the most relevant social and health care problem due to: high incidence among patients who undergo surgery $(20-30 \%$ after general surgical operations and $50-75 \%$ after orthopedic procedures), pulmonary embolism-related mortality rate, and long-term sequelae (postthrombotic syndrome and ulceration). This study has the purpose to establish how patient-related risk factors in elderly (over-70 years old) can modify the effect of laparoscopic cholecystectomy (LC) upon fibrinolysis and coagulation.

\section{Methods}

This observational study included 90 low-risk elder patients for deep vein thrombosis (DVT) undergoing elective LC, without thromboprophylaxis. Preoperatively and after $24 \mathrm{~h}$, we have evaluated following parameters: FDP, PT-INR, aPTT, d-dimer, fibrinogen. Color Doppler scan of the lower extremity has been performed during first post-operative day. Differences before and after surgery have been evaluated according to risk factors.

\section{Results}

We did not appreciate clinically or ultrasound evident DVT. INR $(1.04 \pm 0.06$ vs. $1.12 \pm 0.11, \mathrm{p}<0.0001)$, d-dimer $(0.38 \pm 0.36$ vs. $0.9 \pm 0.64, \mathrm{p}<0.0001)$, plasma fibrinogen (380.8 \pm 74.9 vs.403.8 $\left.\pm 78.8, \mathrm{p}^{1 / 4} 0.0001\right)$ and FDP positivity exhibited statistically significant increase after surgery. Levels of aPTT did not exhibit any significant change. Regarding d-dimer, elder age has been associated with higher pre-operative concentrations; elderly patients have exhibited higher increase in

\footnotetext{
* Correspondence: bruno.amato@unina.it

Department of Clinical Medicine and Surgery, University of Naples Federico II, Via S. Pansini ,5 - 80131 Napoli, Italy
}

d-dimer and FDP after surgery. Male sex has been associated with higher PT - INR and aPTT before surgery, as well as with more pronounced increase in PT- INR during post-operative time; at same time elder age has been attributed with higher PT - INR before surgery.

\section{Conclusions}

Despite no DVT, we have found significant increase in PT, INR, d-dimer, FDP and fibrinogen after laparoscopic surgery. These data could be the results of surgical trauma and pneumoperitoneum effects on the portal vein flow. Elderly subjects and males show major changes in terms of results.

\section{Competing interests \\ The authors declare that they have no competing interests.}

\section{Authors' contributions}

BA: conception and design, interpretation of data, given final approval of the version to be published. RC, GV, TB, MA RR, FF: acquisition of data, drafting the manuscript, given final approval of the version to be published.

\section{Authors' information}

BA: Associate Professor of Surgery at University "Federico II" of Naples, Italy. RC: Post-graduate Doctorate in Vascular Surgery at University "Federico II" of Naples. GV: Resident in General Surgery Training Programme at University "Federico II" of Naples. TB: Resident in General Surgery Training Programme at University "Federico II" of Naples. MA: Resident in General Surgery Training Programme at University "Federico II" of Naples. RR: Resident in General Surgery Training Programme at University "Federico II" of Naples. FF: Resident in General Surgery Training Programme at University "Federico II" of Naples.

\section{Published: 16 September 2013}

\section{References}

1. Dexter SPL, Griffith JP, Grant PJ, MCMahon MJ: Activation of coagulation and fibrinolysis in open and laparoscopic cholecystectomy. Surg Endosc 1996, 10:1069-1074.

2. Prisco D, De Gaudio AR, Carla R, Gori AM, Fedi S, Cella AP, Genuini GF, Abbate R: Videolaparoscopic cholecystectomy induces a hemostasis

\section{(Ciomed Central}


activation of lower grade than does open surgery. Surg Endosc 2000, 14:170-174.

3. Van der Velpen G, Penninckx F, Kerremans R, van Damme J, Arnout J: Interleukin-6 and coagulation-fibrinolysis fluctuations after laparoscopic and conventional cholecystectomy. Surg Endosc 1994, 8:1216-1220.

4. Mayol J, Vincent-Hamelin E, Sarmento JM, Oshiro EO, Diaz-Gonzales J, Tamayo FJ, Fdex-represa JA: Pulmonary embolism following laparoscopic cholecystectomy: report of two cases and review of the literature. Surg Endosc 1994, 8:214-217.

5. Caprini JA, Arcelus JI, Laubach M, Size G, Hoffman KN, Coats RW II, Blattner S: Postoperative hypercoagulability and deep vein thrombosis after laparoscopic cholecystectomy. Surg Endosc 1995, 9:304-309.

6. Patel MI, Hardman DTA, Nicholls D, Fisher CM, Appleberg M: The incidence of deep venous thrombosis after laparoscopic cholecystectomy. Med J Aust 1996, 164:652-656.

7. Magnusson M, Eriksson BI, Kalebo P, Sivertsson R: Is color Doppler ultrasound a sensitive screening method in diagnosing deep vein thrombosis after hip surgery? Thromb Haemost 1996, 75:242-245.

doi:10.1186/1471-2482-13-S1-A8

Cite this article as: Compagna et al.: Venous thromboembolism in laparoscopic surgery: experience in elderly. BMC Surgery 2013 13(Suppl 1):A8.

\section{Submit your next manuscript to BioMed Central and take full advantage of:}

- Convenient online submission

- Thorough peer review

- No space constraints or color figure charges

- Immediate publication on acceptance

- Inclusion in PubMed, CAS, Scopus and Google Scholar

- Research which is freely available for redistribution

Submit your manuscript at www.biomedcentral.com/submit 